\title{
FRAGMEN PERADABAN ISLAM DALAM POTRET HISTORIS PERIODESASI TEOLOGI ISLAM
}

\author{
Abd. Latif \\ Fakultas Ushuluddin dan Studi Agama UIN STS Jambi \\ syeikhabdullatif@gmail.com
}

\begin{abstract}
The following article understands theology in the pragmen of the history of Islamic civilization by mapping the periodization of the systematic development of Islamic theology from time to time. The discussion of this paper is therefore carried out in a simplistic picture of the history of Islamic theology within the limits of the period, which was carried out to avoid a long historical discussion. This paper then maps the period of development of Islamic theology in three major periods, namely: the classical period, the medieval period, and the modern period. All periods will be systematically elaborated in a systematic and regular nature of historical decisions. This work should be judged by prioritizing the discussion of Islamic theology in the perspective of historical thought which is full of social, political and cultural implications.

Tulisan berikut memahami teologi dalam pragmen sejarah peradaban Islam dengan memetakan periodesasi perkembangan sistematis teologi Islam dari masa ke masa. Pembahasan tulisan ini karenanya dilakukan dalam gambaran simplistis terhadap sejarah teologi Islam dalam batasan periode, yang dilakukan untuk menghindari pembahasan sejarah yang panjang. Tulisan ini selanjutnya memetakan periodesasi perkembangan teologi Islam dalam tiga periode besar, yaitu: periode klasik, periode abad pertengahan, dan periode modern. Semua periode akan dijabarkan secara sistematis dalam kekhasan penutusan sejarah yang bersifat sistematis dan teratur. Karya ini kiranya patut ditilik dengan mengedepankan bahasan teologi Islam dalam perspektif pemikiran sejarah yang sarat dengan iplikasi sosial, politik dan budaya.
\end{abstract}

\section{TAJDID Vol. 17, No. 2, Juli - Desember $2018 \mid 181$}


Keywords: Teologi Islam, Periodesasi, Pertarungan, Klasik, Abad Pertengahan, Modern.

\section{Pendahuluan}

W. Montgomery Watt dalam karyanya Islamic Philosophy and Theology, menyatakan bahwa sumber orisinal tentang sejarah perkembangan teologi Islam sangat sedikit dan jikapun ada ditulis secara ringkas. Akan tetapi jika dilacak dari sumber sekunder dari para sejarahwan dan ilmuan di berbagai bidang akan ditemukan informasi yang cukup kaya, walaupun dibutuhkan analisis historis untuk memahami secara kritis perbedaan penamaan tokoh atau hal lainnya. Sumber ini biasa bersumber dari kalangan Mus'tazilah dan al-Asy'ariyah, hingga menghasilkan penafsiran sejarah yang cenderung berbeda. ${ }^{1}$ Artinya penulisan sejarah teologi Islam bukan hal yang sederhana, namun membutuhkan ketekunan dan kehatihatian dalam menafsirkan data yang disertai dengan kejelian untuk bersikap objektif terhadap sumber yang ada.

Masalah telaah sejarah di atas penting untuk diangkat mengingat teologi Islam pada dasarnya melakat dalam kehidupan umat Islam yang telah mengakar kuat dalam pola kehidupan umat Islam, sebagaimana pengaruh mazhab fiqh dalam kehidupan umat Islam. Teologi Islam terbukti memiliki pengaruh yang signifikan terhadap kebudayaan umat Islam dari masa ke masa dari tempat ke tempat. Akan tetapi bagaimana sebenarnya teologi tumbuh dan berkembang dalam kontekstualisasi sejaha Islam Islam? dan bagaimanakah sejarah pertumbuhan dan perkembangan teologi Islam dapat dipetakan?

Dua pertanyaan di atas cukup sederhana, namun membutuhkan kejelian dan akan menjadi tidak sederhana jika ditempatkan dalam pertaruangan ideologi teologi dalam berbagai

${ }^{1}$ W. Montgomery Watt, Islamic Philosophy and Theology (Edinburgh: Edinburgh University Press, 1985), vii.

182 | TAJDID vol. 17, No. 2, Juli - Desember 2018 
alirannya. Untuk itulah penulis mencoba menelisk jauh ke dalam perdebatan sejarah dalam upaya menjawab pertanyaan yang kiranya tidak sesederhana kelihannya. Dalam upaya awal menjawab pertanyaan tersebut, penulis mencoba memberikan gambaran yang sistematis tentang tumbuh dan berkembangangnya teologi dalam Islam dengan membagi sejarah teologi dalam tiga periode, dengan mengutif pada pandangan Bari Yatim, ${ }^{2}$ yaitu periode klasik, abad pertengahan, dan modern.

\section{Pertumbuhan Teologi Islam Periode Klasik}

Mengawali kelahirannya pada masa klasik, teologi Islam mengalami masa kemajuan dan masa disintegrasi yang terjadi antara tahun 650-1250 M., yang disebut sebagai periode klasik. Masa kemajuan meliputi -jika bisa dimasukkan-- masa Rasulullah, masa Khulafa al-Rasyidun, masa Bani Umayyah, dan masa keemasan Daulah Abbasiyah.

Pada masa kemajuan tersebut umat Islam berkembang dari sistem sosial-politik dan kebudayaan yang bersifat keagamaan di Mekkah menjadi sistem kenegaraan di Madinah dan Damaskus pada pemerintahan Bani Umayyah. Seterusnya umat Islam menjadi pusat kebudayaan, peradaban dan keilmuan dunia, di masa keemasan Daulah Abbasiyah di Baghdad. Sedangkan masa disintegrasi ditandai dengan melemahnya kekuasaan khalifah Abbasiyah yang hanya menjadi penguasa bayangan yang dijadikan boneka oleh dinasi-dinasti kecil yang menguasai Baghdad. ${ }^{3}$ Periode klasik ini kemudian ditutup dengan kehancuran Baghdad oleh tentara Mongol yang membawa masa stagnasi di dunia Islam..

Umat Islam begitu gigih menyebarkan misi keislaman sebagai akibat dari tanggung jawab terhadap da'wah Islam pada masa

${ }^{2}$ Badri Yatim, Sejarah Peradaban Islam (Jakarta: RajaGrafindo Persada, 1997), 6.

${ }^{3}$ Lihat M. Masyhur Amin, Dinamika Islam (Sejarah Transformasi dan Kebangkitan) (Yogyakarta: LKPSM, 1995),. 40.

TAJDID vol. 17, No. 2, Juli - Desember 2018 | 183 
Khulafâ al-Rasyidîn, ketika itu, muncul upaya yang besar untuk memperluas dan melebarkan pengaruh dakwah Islamiyah hingga ke luar semenanjung Arabia. Hasilnya adalah wilayah dakwah Islam ketika itupun berkembang pesat, terutama pada masa Usman bin Affan (644-656 M.), di mana kekuasaan umat Islam telah menjangkau benua Eropa yang meliputi Tripoli, Ciprus dan beberapa daerah lainnya.

Selain tujuan dakwah Islamiyah, penaklukan dalam Islam tersebut diusahakan untuk membebaskan kaum yang tertindas dari tangan penguasa lalim yang tiran, sekaligus menjadi corong dakwah yang amat efektif. Sayangnya, perluasan wilayah dakwah Islamiyah -untuk tidak menyebutkan ekspansi Islam-- sempat terhenti, karena preseden pembunuhan Usman, yang terus meruncing pada saat Ali Ibn Abi Thalib (656-661 M.) naik menggantikan Usman. Sejak masa Ali menjadi khalifah, umat Islam terus dilanda pertentangan internal, hingga mengalami banyak perang saudara yang menghasilkan perpecahan teologis, terutama sekali dipicu oleh peristiwa arbitrase. ${ }^{4}$

Arbitrase dalam pandangan sebagian besar umat Islam menjadi momentum tersendiri dalam perkembangan pemikiran Islam, yang mencuatkan persoalan teologis paling awal dalam Islam. Sikap Ali yang menerima poltik Umayyah untuk mengadakan arbitrase, walaupun terpaksa, tidak disetujui oleh sebagian pendukungnya. Pendukung Ali berpendapat bahwa persoalan kemanusiaan tidak dapat diputuskan oleh arbitrase manusia, karena putusan hanya datang dari Allah dengan kembali pada hukum-hukum yang ada dalam al-Qur'an. Golongan tersebut bersemboyan Lâ bukma illa lillâh atau lâ hakama illa Allâh. ${ }^{5}$

${ }^{4}$ Lihat Amin, Dinamika Islam, 56-58 Lihat pula Sayid al-Asghar al-Nazim al-Qamily, al-Fushul al-Mi'ah fi Hayati Amir al-Mu'minin Ali bin Abi Thalib (Muhr Qum: tp., 19920), 510.

${ }^{5}$ Harun Nasution, Teologi Islam: Aliran-aliran Sejarah Analisa Perbandingan (Jakarta: UI Press, 1986), 6.

184 | TAJDID vol. 17, No. 2, Juli - Desember 2018 
Golongan ini kemudian meninggalkan Ali Ibn Abi Thalib yang dipandang telah melakukan kesalahan. Golongan tersebut dalam sejarah Islam menjadi pelopor pembentukan teologi formal Islam, yang terkenal dengan sebutan al-Khawari ${ }^{6}$, yaitu orang yang ke luar dan memisahkan diri.

Selain persoalan teologis tentang yang berhak menentukan hukum, muncul pula persoalan teologis lain yang juga merupakan imbas dari peristiwa politik pada masa Ali, yaitu persoalan kedudukan orang yang berdosa besar dalam Islam apakah ia kafir atau mukmin? Pada tahap ini muncul tiga aliran teologis formal yang masing-masing memiliki argumentasi teologisnya sendirisendiri, yaitu: Pertama, aliran Khawarij berpendapat bahwa orang yang berdosa besar adalah kafir, dalam arti keluar dari Islam atau tegasnya murtad dan wajib di bunuh; kedua, aliran Murji'ab', menegaskan orang yang berbuat dosa besar tetap mukmin dan bukan kafir, soal dosa yang mereka lakukan, terpulang kepada Allah untuk memutuskan apakah diampuni atau tidak; ketiga, aliran Mu'tarilah', melihat orang yang berdosa besar bukan kafir dan bukan pula mukmin, mereka berada pada posisi di antara mukmin dan kafir (al-manzilab bain al-manzilitain). ${ }^{10}$

Pada tataran teologis yang lebih universal, khususnya tentang perbuatan manusia, terdapat pula dua kubu aliran teologi yang saling bertentangan, yaitu al-Qadariyah ${ }^{11}$ dan al-Jabariyab ${ }^{12}$. Qadariyah

${ }^{6}$ Kenneth W. Morgan, Islam the Staight Path, (Terj.) Abusalamah et.al., Islam Djalan Mutlak: Islam ditafsirkan oleh Kaum Muslimin (Jakarta: Pembangunan Djakarta, 1963), 16.

${ }^{7}$ Muhammad bin Abdul Karim al-Syahrastani, al-Mibal wa al-Nihal (Beirut: Dar al-Fikr, tt), 149.

${ }^{8}$ Lihat Nasution, Teologi Islam, 24-26.

${ }_{9}$ M. Yunan Yusuf, Alam Pikiran Islam: Pemikiran Kalam (Jakarta: Perkasa, 1990), 37-46.

${ }^{10}$ Lihat Nasution, Teologi Islam, 7.

${ }^{11}$ Lebih lengkap lihat Luis Ma'luf, al-Mu'jam fi al-'Alam (Bairut: Dar alMasyriq, tt),. 513.

${ }^{12}$ Nasution, Teologi Islam, 33. 
berpendapat, bahwa manusia mempunyai kemerdekaan dalam kehendak dan perbuatan (free will and free act), sedangkan Jabariyah berpendapat sebaliknya, manusia tidak memiliki kemerdekaan dalam kehendak dan perbuatan. Segala tingkah laku manusia pada dasarnya ditentukan oleh Tuhan. ${ }^{13}$

Teologi Islam dalam perkembangannya kemudian memunculkan dua kubu aliran teologis yang terpengaruh kuat oleh nuansa konfrontatif antara Qadariyah dan Jabariyah, yang tampak nyata sebagai perpanjangan tersendiri dari dua corak aliran teologi tersebut. Kedua kubu aliran tersebut adalah Mu'tarilah dan alAsy'ariyah. ${ }^{14}$ Kedua teologi tersebut merupakan dua aliran teologi yang amat dominan pada perkembangan pemikiran Islam selanjutnya.

Mu'tazilah dalam perkembangannya banyak menyerap berbagai pemikiran rasional berdasarkan karya terjemahan filsafat dan pengetahuan Yunani ke dalam bahasa Arab, ${ }^{15}$ sehingga pengaruh ilmu pengetahuan dan filsafat Yunani sangat kental dalam metode berpikir mereka yang rasional. Mu'tarilah secara lebih intens mengadopsi metode berpikir rasional dalam pemikiran teologi yang bercorak liberal dan rasional. ${ }^{16}$ Pada sisi lain, alAsy'ariyah merupakan reaksi terhadap Mu'tazilah, kareanya banyak bertumpu pada penalaran yang bersumber pada wahyu dan sunnah, dengan tetap mempertahankan rasio (ta'wil) sebagai penalaran sekunder. ${ }^{17}$ Dengan corak metode berpikir demikian, alAsy'ariyah berkecendrungan menjadi penengah antara corak pikir rasional dengan corak pikir tradisional yang amat tekstual. Namun

${ }^{13}$ Nasution, Teologi Islam, 7.

${ }^{14}$ Lihat Nasution, Teologi Islam, 65-66.

${ }^{15}$ Nasution, Teologi Islam, 32-36.

${ }^{16}$ Nasution, Teologi Islam, 8.

${ }^{17}$ Lihat Nurcholish Madjid, Islam Doktrin dan Peradaban: Sebuah Telaah Kritis tentang Masalab Keimanan, Kemanusiaan, dan Kemodernan (Jakarta: Paramadina, 1992), 270-271.

186 | TAJDID vol. 17, No. 2, Juli - Desember 2018 
karena dialektikanya yang berbeda, hasil pemikiran teologi alAsy'ariyah banyak berseberangan dengan pandangan Mutazilah. Kecenderungan al-Asy'ariyah terhadap ilmu pengetahuanpun berbeda dengan $M u^{\prime}$ tarilah, bila Mu'tarilah memiliki kecenderungan kuat pada ilmu pengetahuan secara detail. Maka seperti dikatakan Stanton, al-Asy'ariyah kurang tertarik pada pengembangan dan jabaran ilmu pengetahuan secara detail, khususnya pada penjelasan sebab-akibat fenomena alam dan tingkah laku manusia dalam ilmu alam dan sosial. ${ }^{18}$

Abu Hasan 'Ali Ibn Isma'il al-'Asy'ari (873-935 M) menjadi pendiri al-Asy'ariyah, ia meninggalkan Mu'tazilah dan membentuk aliran teologi baru. Teologi tersebut berhasil meredam pengaruh Mu'tåilah secara radikal dengan membawa implikasi pada pemikiran fatalis bagi kehidupan umat Islam. Berdasarkan pandangan yang menekankan pada wahyu, mereka menolak eksistensi kebebasan manusia, memahami semua peristiwa terjadi karena sebab vertikal, yaitu karena kehendak Tuhan, yang berimplikasi pada penolakan terthadap hukum kausalitas. ${ }^{19}$

Kedua aliran di atas muncul pada periode klasik, namun pada periode ini umumnya umat Islam lebih dipengaruhi oleh teologi yang bercorak rasional atau falsafi. Harun Nasution mengidentifikasi aliran ini sebagai teologi Sunnatullah atau teologi natural law, teologi jenis ini kental dalam teologi Qadariyah dan Mu'tazilah yang dalam batas tertentu berdekatan alam pikiran alMaturidiyah, walaupun bersama dengan al-Asy'ariyah ia dikategorikan sebagai Abl Sunnah wa al-Jama'ah. Adapun ciri-ciri teologi sunnatullah tersebut adalah: (1) Kedudukan akal ditinggikan; (2) memandang ada kebebasan manusia dalam berkehendak dan berbuat; (3) kebebasan berpikir yang diikat oleh

${ }^{18}$ Charles Michael Stanton (terj.), Pendidikan Tinggi dalam Islam (Jakarta: Logos Publishing House, 1994), 36.

${ }^{19}$ Stanton, Pendidikan Tinggi dalam Islam, 58-59.

TAJDID vol. 17, No. 2, Juli - Desember 2018 | 187 
ajaran dasar al-Qur'an dan hadits hanya sedikit; (4) percaya pada hukum kausalitas; (5) mengambil arti metaforis dalam memahami ayat, serta; (6) dinamika amat terbuka dalam sikap dan berpikir. ${ }^{20}$

Hingga di sini tampak bahwa substansi makna teologi pada periode klasik diletakkan pada pemahaman teologi sebagai keilmuan praktis yang memiliki kontekstualisasi dengan urusan manusia. Pemaknaan yang demikianlah yang kemudian memberikan dampak yang besar dalam pencapaian kemajuan ilmu pengetahuan umat Islam di masa keemasan. ${ }^{21}$ Sifat rasionalitas dalam teologi klasik memang menonjol, bahkan juga terasa dalam panorama pemikiran al-Asy'ari. ${ }^{22}$

\section{Simplifikasi Pemahaman Teologi Islam Periode Pertengahan}

Periode pertengahan berlangsung antara tahun 1250-1800 M., meliputi masa kemunduran budaya dan peradaban Islam yang diawali dengan kehancuran Baghdad sebagai pusat budaya Islam. Pada masa ini berdiri tiga kerajaan besar yaitu Daulah Turki Utsmani di Turki, Daulah Shafawiyah di Iran, dan Daulah Mongol di India. ${ }^{23}$ Perkembangan teologi pada periode pertengahan adalah hasil penyederhanaan dari perkembangan teologi masa disintegrasi di penghujung periode klasik yang ditandai dengan disingkirkannya filsafat sebagai metode pemahaman agama. Dalam praktiknya metode filsafat yang awalnya dijadikan alat untuk menjelaskan teks wahyu dalam kaitannya dengan problem dasar relasi manusia, alam dan Tuhan, telah diarahkan secara terbatas semata-mata untuk menjustifikasi atau merasionalisasi wahyu. Dengan demikian

${ }^{20}$ Saiful Muzani (ed.), Islam Rasional: Gagasan dan Pemikiran Prof. Dr. Harun Nasution (Bandung: Mizan, 1995), 112.

${ }^{21}$ Mengenai riwayat hidup para filosof baca Harun Nasution, Filsafat dan Mistisisme dalam Islam (Jakarta: Bulan Bintang, 1990), 10-47.

${ }^{22}$ Madjid, Islam Doktrin dan Peradaban, 280-281.

${ }^{23}$ Amin, Dinamika Islam, 58.

188 | TAJDID vol. 17, No. 2, Juli - Desember 2018 
filsafat yang cukup dominan dalam alam pikir Mu'tazilah pada periode klasik telah menjadi semacam antek suruhan teologi, yang mengakibatkan otoritas filsafat sebagai pengetahuan menjadi kabur dan kurang kritis terhadap agama. ${ }^{24}$ Hasilnya trtadisi berpikir kritis dalam filsafat menjadi pudar.

Pada periode ini al-Asy'ariyah menempati posisi sentral dalam dunia Islam dan telah menjadi faham yang dianut oleh mayoritas umat Islam. Namun demikian terjadi pergeseran corak pikir dalam aliran al-Asy'ariyah saat itu, jika pada permulaanya al-Asy'ariyah masih kental dengan metode filsafatnya, terlihat dalam argumentasinya menentang paham $M u^{\prime}$ tazilah, maka pada periode ini al-Asy'ariyah telah benar-benar menjadi momok yang menakutkan bagi filsafat dengan tantangannya terhadap filsafat yang dinilai oleh mutakallimin yang tergabung dalam Abl al-Sunnah wa al-Jamaah (al-Asy'ariyah dan al-Maturidiyah) sebagai ajaran yang bertentangan dengan wahyu, terutama dengan doktrin kekekalan alam dan doktrin tentang Tuhan yang tidak mengetahui hal partikular, atau dalam istilah lain, Tuhan terpisah dari ciptaanNya. ${ }^{25}$ Bahkan filsafat juga telah dicap sebagai perusak aqidah umat. Akibatnya, ajaran-ajaran teologi Mu'tazilah yang banyak dibangun atas metode filsafat peripatetik (masysya'iyyah) ${ }^{26}$ yang kental dengan filsafat Aristotelianis dan sedikit terpengaruh oleh NeoPlatonisme tidak terhindar dari serangan komunitas muslim ortodoks ataupun "tradisionalis". 27

Periode abad pertengahan ini dinilai oleh Harun Nasution ditandai dengan pudarnya pamor teologi Sunnatullah atau teologi bercorak rasional dan falsafi dalam dunia Islam, yang berpindah ke

${ }^{24}$ Agus Purwadi, Teologi Filsafat dan Sains (Malang: UMM-Press, 2002), 57.

${ }^{25}$ Budhy Munawwar Rachman, "Tradisi dan Masa Depan Filsafat Islam", dalam Ulumul Qur'an, No. 3 Vol. I, 1989, 102.

${ }^{26}$ Murtadha Muthahhari, Tema-tema Filsafat Islam (Bandung: Mizan, 1993), 29-30.

${ }^{27}$ Purwadi, Teologi Filsafat dan Sains, 58.

TAJDID Vol. 17, No. 2, Juli - Desember 2018 | 189 
Barat melalui mahasiswa Eropa yang belajar di Andalusia sebagai satu-satunya penerus tradisi filsafat dunia Islam ketika itu. ${ }^{28}$ Implikasinya, menurut sebagian ahli, al-Asy'ariyah secara tidak disadari telah membawa kesadaran umat bergerak linear sebatas dimensi mistis, mereduksi kesadaran kosmik manusia dalam kungkungan paradigma yang sangat teosentris, atas dasar penyangkalan terhadap peran kosmis manusia sebagai khalifah sekaligus subjek yang dapat menentukan nasibnya sendiri. ${ }^{29}$ Atas dasar tersebut, Syed Hossein Nasr menyatakan al-Asy'ariyah tidak memberikan sumbangan berarti bagi kemajuan sains dalam Islam. $^{30}$

Pandangan lain mengungkapkan bahwa al-Asy'ariyah bukanlah satu-satunya faktor penyebab pemudaran tradisi keilmuan umat Islam, karena dalam kenyataannya banyak faktor yang turut berpengaruh terhadap kemunduruan umat Islam periode pertengahan atau periode kemunduran, seperti perpecahan politik, ekonomi, dan tradisi kemasyarakatan Islam sendiri yang telah berubah dari koridor awalnya. Dalam kenyataan tersebut ada indikasi yang layak dicermati, bahwa inti pemahaman al-Asy'ari yang amat kaya dan tidak kurang rasionalnya dengan Mu'tazilah, tampaknya banyak disalahartikan dan disederhanakan oleh masyarakat awam Islam yang menganutnya. Ajaran al-Asy'ariyah karena interpretasi tertentu dirasakan mendukung tradisi fatalis, yang memang menjadi tradisi induk beberapa bangsa yang berkuasa ketika itu terutama Turki Uthmani.

Pemikiran teologi Islam yang berkecenderungan fatalis ini turut dikondisikan pula oleh situasi dan tantangan historis yang erat kaitannya dengan kepentingan politik suatu rezim. Kenyataan

${ }^{28}$ Lihat Muzani (ed.), Islam Rasional, 116.

${ }^{29}$ Muzani (ed.), Islam Rasional, 60.

${ }^{30}$ Lihat Syed Hossein Nasr, Intelektual Islam, Teologi, Filsafat dan Gnosis (Yogyakarta: CIIS Press, 1995), 23.

190 | TAJDID vol. 17, No. 2, Juli - Desember 2018 
ini hal yang wajar, karena teologi sendiri awalnya terlahir oleh adanya pertentangan politik antara 'Ali bin Abi Thalib dan Mu'awiyah, hingga akhirnya lebih cenderung dijadikan sebagai sarana pengokohan suatu pandangan politis tertentu, dengan dalih sebagai ajaran teologis-dogmatis yang diperkuat oleh ayat atau hadith yang ditafsirkan dan disesuaikan dengan cara pikir yang dianut oleh aliran teologi masing-masing... ${ }^{31}$

Secara politis pengaruh al-Asy'ariyah dalam periode pertengahan yang dominan adalah berkat sokongan otoritas penguasa, terutama dinasti Saljuk yang mampu menyebarluaskan paham al-Asy'ariyah dan patronnya Syafi'iyah, hingga menjadikannya sebagai paham yang dianut oleh mayoritas umat Islam. Berkat argumentasi teologis yang melenakan, kalangan awam dibuat terlena dalam tindakan apologi tekstualis yang melibatkan teks wahyu sebagai legitimasi. ${ }^{32}$

Perkembangan teologi pada periode abad pertengahan ini ditandai pula oleh corak teologi yang dogmatis di mana pandangan teologis banyak dijustifikasi berdasarkan wahyu, yang secara perlahan membawa suatu kekaburan antara wahyu dan produk pemikiran teologi, mengingat pandangan teologi selalu dikaitkan dengan ayat-ayat al-Qur'an. Dalam proses pembauran tersebut, produk rumusan teologi yang relatif akhirnya diklaim dalam normativitas dan finalitas wahyu. Hal ini yang menjadi awal kesulitan umat Islam, hingga dewasa ini untuk membedakan antara sisi ajaran wahyu yang bersifat esensial dengan sisi tuntutan sejarah kemanusiaan yang bersifat lokal profan, karena keduanya terlanjur disamaratakan sebagai yang esensial dan normatif. ${ }^{33}$

${ }^{31}$ M. Amin Abdullah, Falsafah Kalam di Era Postmodernisme (Yogyakarta: Pustaka Pelajar, 1995), 50.

${ }^{32}$ Disari dari Binyamin Abrahamov, Islamic Theology: Tradisonalism and Rationalism, (terj), Nuruddin Hidayat, Ilmu Kalam: Tradisonalisme dan Rasionalisme dalam Teologi Islam (Jakarta: Serambi Ilmu Semesta, 2002), 81-82.

${ }^{33}$ Abrahamov, Ilmu Kalam, 52. 
Corak pemikiran teologi yang demikian inilah yang mewarnai teologi Islam ketika itu, bahwa pada periode pertengahan umat Islam lebih dikuasai oleh corak teologi bercorak wahyi, sebuah teologi yang bersifat amat tekstualis hingga hasil rumusannya sangatlah metafisis, dengan ciri-ciri, merendahkan kedudukan akal, kemauan dan kehendak manusia dilihat dalam ketidakbebasan, sikap berpikir amat statis, tidak percaya pada kausalitas, al-Qur'an dan Hadits dipahami secara tekstual, serta kebebasan berpikir banyak diikat oleh dogma agama. ${ }^{34}$

Imbas dari corak pemikiran teologi demikian ini adalah hanya memahami teologi sebatas ilmu tentang Tuhan dalam kawasan metafisika, yang kentara dalam rumusan teologi yang tidak praktis dan kurang aplikabel dalam kehidupan nyata. Namun tidak dapat disangkal teologi abad pertengahan banyak mendorong usaha transmisi tradisi Islam klasik secara ketat, walaupun dilakukan secara tidak kreatif, terutama melalui institusi tarekat yang kemudian berkembang pesat di dunia Islam.

\section{"Kebangkitan" Teologi Islam pada Periode Modern}

Periode modern terjadi antara tahun 1800 hingga sekarang. Masa ini lahir sebagai imbas dari kolonialisasi yang melanda dihampir seluruh dunia Islam. Ketika itu umat Islam mulai banyak belajar dari Barat dalam rangka mengembalikan balance of power. ${ }^{35}$ Periode ini umumnya ditandai dengan munculnya usaha umat Islam mengatasi problematika teologis umat Islam periode pertengahan yang mengungkung. Usaha tersebut umumnya dilakukan oleh kelompok pembaru Islam yang dapat diklasifikasi dalam beberapa corak mulai dari revivalisme pra-modernis yang muncul pada abad ke-18 dan 19 di Arabia, India dan Afrika, melalui pembukaan kembali pintu ijtihad dan mengeyahkan segala

${ }^{34}$ Muzani (ed.), Islam Rasional, 60.

35 Amin, Dinamika Islam, 41. 
bentuk tahayul yang ditanamkan oleh sufisme, serta meninggalkan gagasan tentang kemapanan mazhab. Gerakan revivalisme pramodernis dikumandangkan oleh gerakan Wahabiyah di Arab, Syah Waliyullah di India dan gerakan Sanusiah serta Fulaniyah di Afrika. ${ }^{36}$

Revivalisme pra-modernis merupakan gerbang periode modern dalam pemikiran Islam yang ditandai dengan munculnya kesadaran umat Islam untuk melepaskan diri dari belenggu kekuatan asing yang menjajah berbagai wilayah dunia Islam. Revivalisme pra-modernis secara umum berpandangan bahwa segala kebid'ahan dikategorikan sebagai yang sesat. Gerakan tersebut hanya memandang idealisme yang suprematif pada masa lampau, lalu berkeyakinan bahwa segala yang baru (bid'ah) harus dihancurkan. Karena itu identifikasi wahabiyah dewasa ini identik dengan penganut faham salafiyah yang secara radikal berpandangan amat transendental dan merupakan gerakan revolusi spritual transendental. ${ }^{37}$ Substansi gerakan ini baru menyentuh perubahan tradisi umat Islam kepada tradisi aslinya dan belum diarahkan pada masalah yang lebih luas seperti masalah perlunya pembangunan ekonomi dan sosial.

Ciri-ciri umum dari gerakan pemurnian tersebut adalah: ada keprihatinan yang mendalam terhadap degenerasi sosio-moral umat Islam dan berusaha untuk mengubahnya, sarat dengan himbauan kembali pada Islam sejati dan mengeyahkan segala bentuk takhayul yang ditanamkan oleh sufisme, meninggalkan gagasan tentang kemapanan dan finalitas mazhab, serta berupaya untuk melaksanakan ijtihad, sarat dengan himbauan untuk mengenyahkan segala bentuk pandangan yang mengungkung

36 Lihat Fazlur Rahman (terj.) Metode dan Alternatif Neomodernisme Islam (Bandung: Mizan, 1994), 18.

${ }^{37}$ Lihat Hasan Sho'ub, Islam dan Revolusi Pemikiran: Dialog Kreatif Ketuhanan dan Kemanusiaan (Surabaya: Risalah Gusti, 1997), 67-67.

TAJDID Vol. 17, No. 2, Juli - Desember 2018 | 193 
kebebasan manusia, penuh dengan himbauan untuk melaksanakan pembaruan, bahkan melalui kekuatan senjata jika diperlukan.

Gerakan revivalisme pra-modernis dalam kenyataannya belum mampu menggelorakan semangat teologis yang kondusif bagi pembangunan dunia Islam secara keseluruhan, karena mereka tetap terpengaruh oleh sikap ekstrim teologi periode pertengahan yang bercorak wahyi terutama pada penekanan untuk melaksanakan pembaruan walaupun dengan kekuatan bersenjata. ${ }^{38}$ Hal ini jelas mengindikasikan masih kentalnya truth claim dalam pembaruan tersebut, sehingga mendorong munculnya gerakan pembaruan baru dalam dunia Islam yang dikenal dengan modernisme Islam yang sangat terpengaruh dan mengidolakan Barat modern.

Modernisme Islam yang muncul pada paruh abad ke-19 dan awal abad ke-20 sangat berbeda dengan revivalisme pra-modernis. Modernisme Islam sangat terpola dan terpengaruh oleh metode pemikiran Barat, dengan memfokuskan pada pembaharuan terhadap isi ijtihad, khususnya masalah pembaruan sosial, politik, pendidikan, status wanita, ataupun HAM yang muncul dari hasil persentuhannya dengan Barat. Pola penafsiran yang ditawarkan oleh para pembaru modernisme klasik, walaupun tetap bertumpu pada al-Qur'an dan sunnah Nabi dalam artian historis (biografi Nabi), amat skeptis terhadap hadits tekstual Nabi yang tidak ditopang oleh kritisisme ilmiah. ${ }^{39}$ Gerakan tersebut dikenal juga dengan modernisme klasik karena ia merupakan gerakan pertama yang sangat terpola pada pemikiran Barat, yang dilakukan dengan mengadopsi seluruh metode pemikiran Barat modern.

Sulthan Mahmud II (1784-1839 M) merupakan eksponen awal yang yang banyak melakukan pembaruan dalam struktur

${ }^{38}$ Sho'ub, Islam dan Revolusi Pemikiran, 18.

${ }^{39}$ Rahman (terj.) Metode dan Alternatif Neomodernisme Islam, 18-19.

194 | TAJDID vol. 17, No. 2, Juli - Desember 2018 
pemerintahan terutama dengan membatasi wewenang penguasa yang melampaui dalam struktur pemerintahan aristokrasi. Dalam bidang militer Mahmud II melakukan pembaruan dengan memakai sistem militer Barat, pemerintahan, selain itu ia juga banyak melakukan pembaruan dalam bidang pendidikan melalui wajib belajar dan perubahan kurikulum madrasah sesuai dengan tuntutan zaman. ${ }^{40}$ Tokoh lain yang dapat secara tegas dikatakan sebagai pengusung modernisme Islam adalah Zia Gokalp (1875-1924 M.) yang merupakan teoritikus gerakan Turkisme yang ia elaborasi dari pemikiran Emile Durkheim. Dalam pemikirannya Gokalp sampai pada keyakinan untuk membangun nasionalisme berdasarkan kebudayaan bukan ras atau bangsa. Tokoh lain yang menonjol dari modernisme Islam adalah Mustafa Kemal Attaturk (1881-1938 M.), yang berupaya memisahkan agama dari negara, di mana seluruh perangkat kenegaraan harus didasarkan pada praktik Barat, baik dalam hukum, bahasa, dan budaya. Sedangkan segala hal yang bernuansa Arab harus digantikan dengan nuansa Turki yang khas. ${ }^{41}$

Selain itu, di India, salah satu tokoh berpengaruh dari Modernisme Islam adalah tokoh sekaliber Muhammad Iqbal (1877 M.), yang berupaya menyegarkan kelembaban pemikiran Islam melalui karya fenomenalnya the Reconstruction of Religius Thought in Islam. Dalam karya tersebut Iqbal berupaya mengajak kaum muslim untuk kembali pada pemikiran keagamaan yang sejati. ${ }^{42}$

Pada akhirnya, muncul pula neorevivalisme atau revivalisme pascamodernisme. Gerakan pembaruan ini muncul dengan semangat yang besar membedakan dirinya dari Barat, yang membuatnya

${ }^{40}$ Marshall G.S. Hodgson, The Venture of Islam (New York: The University of Chicago Press,1974), 106-107.

${ }^{41}$ Syafiq A. Mughni, Sejarah Kebudayaan Islam di Turki (Jakarta: Logos, 1997), 143-150.

${ }^{42}$ Ali Rahnema, Pioneers of Islamic Revival, (terj.) Ilyas Hasan, Para Printis Zaman Baru Islam (Bandung: Mizan, 1995), 9-10.

TAJDID Vol. 17, No. 2, Juli - Desember 2018 | 195 
walaupun mengusung pemikiran modernisme Islam berupa pemahaman bahwa Islam mencakup segala aspek kehidupan manusia, namun secara metodis menolak metode dan semangat modernisme Islam yang Barat sentris. Mereka secara tegas menempatkan diri sebagai reaksi sekaligus penerus pembaruan yang dilakukan oleh modernisme Islam. Namun demikian sayang sekali corak pembaruan ini kurang dapat mengembangkan metode yang baru bagi pembaruan Islam termasuk dalam teologi. ${ }^{43}$ Gerakan revivalisme pasca modernisme di atas dipelopori oleh tokoh-tokoh pembaru Islam seperti Fazlur Rahman, Hassan Hanafi, Isma’il Raji al-Faruqi, dan lainya.

Gerakan pembaruan Islam di atas sungguhpun sangat besar pengaruhnya bagi pembaruan Islam, belum mampu membuat kemajuan yang berarti dalam pemikiran Islam, terlebih dalam praktik pembangunan Islam secara kaffah. Masing-masing tetap memiliki kelemahan yang mencolok. Revivalisme pramodernis cenderung meminggirkan sufisme yang merupakan bagian erat dalam tradisi Islam. Pada sisi lain, modernisme Islam yang teramat rasional cenderung melupakan hadits tekstual Nabi. Sedangkan neorevivalisme walaupun mampu melepaskan diri dari rasionalisme Barat namun tidak dapat menawarkan metode dan konsep yang nyata dalam pembaruan Islam. Berdasarkan kelemahan-kelemahan tersebut, nyata ketiga model pembaruan di atas masih belum dapat diharapkan untuk membawa kamajuan bagi dunia Islam untuk dijadikan landasan paradigma teologi pembangunan Islam.

Dewasa ini, dapat dikatakan ciri teologi Islam periode pertengahan, terutama al-Asy'ariyah dengan berbagai kelebihan dan kelemahannya, tidak dapat dikatakan hilang, pengaruh pemikiran dan metode pemikiran yang dianut masih sangat mengental dan mempengaruhi umat Islam. Pengaruh aliran teologi tersebut masih

${ }^{43}$ Rahman (terj.) Metode dan Alternatif Neomodernisme Islam, 19.

196 | TAJDID vol. 17, No. 2, Juli - Desember 2018 
amat menguasai umat Islam, bahkan senantiasa hidup dalam pemikiran umat Islam, tanpa pembaruan pemikiran teologi Islam yang berarti.

Buktinya, pembaruan pemikiran Islam lebih banyak bersifat apologia ataupun tidak metodis, dan masih terformat dalam pemikiran teologi periode pertengahan sehingga tidak mampu memberikan sumbangsi berarti pada peretasan teologi yang benarbenar baru dan muncul dari problematika kemodernan. Dalam wacana akademik misalnya, teologi yang diulas selalu terpola pada teologi periode klasik dan pertengahan, sedangkan pemikiran pembaruan tidak mampu memberikan pandangan yang berarti bagi perumusan teologi yang baru, karena masing-masing memiliki kelemahan tersendiri.

Arkoun, dengan tegas mengkhawatirkan hal tersebut, ketika ia membandingkan teologi periode pertengahan dengan teologi umat Islam dewasa ini. Katanya, salah satu ciri teologi periode pertengahan (terutama al-Asy'ariyah) selalu ingin menerima data yang diwahyukan secara setia dan utuh. Hal tersebut dapat mengakibatkan pemikiran Islam menjadi terkungkung dalam ketertutupan logosentrisme, yang berkecenderungan membedabedakan, mensistematisasikan, menggolong-golongkan, serta mengkotak-kotakkan objek kajiannya. ${ }^{44}$

Secara menyeluruh Arkoun menilai pola pemikiran Islam modern umumnya masih dikuasai oleh logosentrisme periode pertengahan, kental dengan ciri-ciri pemikiran khas abad kemunduran, yaitu: Pertama, masih sangat dikuasai oleh nalar yang dogmatis dan sangat terkait dengan Kebenaran abadi (Tuhan). Lebih bersifat estetis-etis dari pada ilmiah. Kedua, nalar yang bertugas mengenali kembali kebenaran (fungsi 'aql) telah menjadi sempit, hanya berkutat dalam wilayah tempat kelahirannya saja,

\footnotetext{
${ }^{44}$ Suadi Putro, Mobammed Arkoun Tentang Islam dan Modernitas (Jakarta: Paramadina, 1995), 36-37.
}

TAJDID Vol. 17, No. 2, Juli - Desember 2018 
yaitu pada bidang-bidang metafisika, eskatologi, moral, serta hukum. Ketiga, dalam kegiatannya, nalar hanya difokuskan pada rumusan-rumusan umum dengan menggunakan metode analogi, implikasi, dan oposisi. Keempat, terdapat usaha untuk menggunakan temuan data empiris sederhana untuk menjustifikasi atau melegitimasi bagi kebenaran penafsiran tertentu, hingga pemikiran Islam lebih bersifat apologetik. Kelima, pemikiran Islam cenderung menutup diri dan tidak memperhatikan matra kesejarahan, sosial, budaya, etnik, dengan kecenderungan memunculkan wacana tunggal yang harus diikuti secara seragam dalam arti taqlid. Keenam, pemikiran Islam lebih mementingkan suatu wacana lahir yang terproyeksi dalam spektrum bahasa yang terbatas, sesuai dengan kaidah-kaidah bahasa, dan berkecenderungan untuk mengulang-ulang sesuatu yang lama. Adapun wacana bathin yang melampaui batas-batas logosentris melalui pengalaman spritual, banyak diabaikan. ${ }^{45}$

Penjara logosentrisme ataupun doktriner yang sangat kental dalam sejarah Islam abad tengah membawa kaum Muslim secara umum untuk membenarkan penafsiran kelompoknya masingmasing, dan secara berbalik mengabaikan penafsiran kelompok lain sebagai penafsiran yang tidak diakui atau salah. Kaum Muslim pada tahap ini tidak lagi mampu untuk membedakan antara yang bersifat Wahyu Ilahi murni dengan produk penafsiran wahyu yang sebenarnya tidaklah sakral. Keadaan ini, pada penampakan sejarah semakin menjauhkan produk penafsiran umat Islam yang doktriner dari matra-matra sosial, budaya-politik, sejarah serta psikologis umat Islam suatu zaman. ${ }^{46}$ Akibatnya teologi sebagai salah satu produk penafsiran wahyu menjadi tidak realistis dan tidak bersentuhan dengan kebutuhan hidup manusia secara langsung.

45Putro, Mohammed Arkoun Tentang Islam dan Modernitas, 38.

46Putro, Mohammed Arkoun Tentang Islam dan Modernitas, 40.

198 | TAJDID vol. 17, No. 2, Juli - Desember 2018 
Akibatnya teologi menjadi mandul tidak mampu menjawab berbagai problematika dalam kemodernan seperti problem demokrasi, hak asasi manusia (HAM), toleransi, status wanita, dan sebagainya, tetap meninggalkan problematika intelektual dalam pemikiran Islam, yang terkait erat dengan problem rasionalitas. ${ }^{47}$ Umat Islam cenderung memberikan jawaban yang terpola pada paham yang mengungkung. Dalam keterkungkungan teologis ini, amat sulit mengharapkan teologi dapat menjawab sejumlah problem yang dimunculkan dalam kemodernan.

Abd 'Ala dalam sebuah artikelnya menyatakan bahwa teologi kontemporer dewasa ini merupakan teologi yang "mandul", tidak mampu menangkap perkembangan realitas kehidupan manusia. Teologi yang berkembang dewasa ini masih sangat didominasi oleh difensif teologia yang berorientasi pada Tuhan atau hal-hal transenden (theistic oriented) yang ekslusif. Teologi semacam ini hanya menitikberatkan bahasannya pada upaya dan cara memperkokoh keimanan transenden semata. Nilai-nilai immanen yang terkandung dalam ajaran agama (aqidah dan ibadah) dibiarkan terbengkalai. ${ }^{48}$

Ringkas kata, teologi Islam kontemporer dewasa ini pada dasarnya tidak berbeda jauh dengan teologi periode pertengahan, tetap terkungkung dalam penjara logosentrisme ataupun dogmatisme. Teologi dewasa ini bahkan dapat dikatakan lebih buruk, karena tidak didasarkan pada keadaan nyata zaman modern. Hal inilah yang menjadikan teologi kontemporer menjadi teologi yang mandul yang tidak memiliki keterkaitan dengan kehidupan nyata manusia modern. Sifatnya yang difensif, malah

${ }^{47} \mathrm{~W}$. Montgomery Watt, The Formative Period of Islamic Thought (Edinbergh: The University Press, 1973), 284.

${ }^{48}$ Lihat Abd A'la, "Kehidupan Kontemporer dalam Teologi yang Mandul”, Kompas, Jum'at, 9 November 2001. 
terkadang menjadi pemicu berbagai kekerasan antar umat beragama ataupun intern umat beragama.

\section{Penutup}

Setelah melakukan jabaran di atas, dapat dikatakan bahwa teologi Islam dalam perkembangannya telah mengalami perubahan makna yang cukup berarti mulai dari pengertian yang bersifat antropologik menuju pengertian yang theologik.semua itu tidak terlepas dari kerangka pemikiran yang menjadi setting suatu generasi dalam memahami dan memaknai teologi. Sebagai akibatnya teologi yang dikenal dewasa ini identik dengan persoalan transendental yang tidak tersentuh dan sulit dihubungkan dengan realitas dan problematika yang dihadapi umat Islam baik dulu maupun sekarang.

\section{Daftar Pustaka}

A'la, Abd. "Kehidupan Kontemporer dalam Teologi yang Mandul", Kompas, Jum'at, 9 November 2001.

Abdullah, M. Amin. Falsafah Kalam di Era Postmodernisme. Yogyakarta: Pustaka Pelajar, 1995.

Abrahamov, Binyamin. "Islamic Theology: Tradisonalism and Rationalism”. Terjemah Nuruddin Hidayat, Ilmu Kalam: Tradisonalisme dan Rasionalisme dalam Teologi Islam. Jakarta: Serambi Ilmu Semesta, 2002.

Amin, M. Masyhur. Dinamika Islam (Sejarah Transformasi dan Kebangkitan). Yogyakarta: LKPSM, 1995.

Hodgson, Marshall G.S. The Venture of Islam. New York: The University of Chicago Press,1974.

Ma'luf, Luis. Al-Mu'jam fi al-'Alam. Bairut: Dar al-Masyriq, tt.

Madjid, Nurcholish. Islam Doktrin dan Peradaban: Sebuah Telaah Kritis tentang Masalah Keimanan, Kemanusiaan, dan Kemodernan. Jakarta: Paramadina, 1992.

200 | TAJDID vol. 17, No. 2, Juli - Desember 2018 
Morgan, Kenneth W. Islam the Staight Path. Terjemah Abusalamah et.al., Islam Djalan Mutlak: Islam ditafsirkan oleh Kaum Muslimin. Jakarta: Pembangunan Djakarta, 1963.

Mughni, Syafiq A. Sejarah Kebudayaan Islam di Turki. Jakarta: Logos, 1997.

Muthahhari, Murtadha. Tema-tema Filsafat Islam. Bandung: Mizan, 1993.

Muzani, Saiful (ed.). Islam Rasional: Gagasan dan Pemikiran Prof. Dr. Harun Nasution. Bandung: Mizan, 1995.

Nasr, Syed Hossein. Intelektual Islam, Teologi, Filsafat dan Gnosis. Yogyakarta: CIIS Press, 1995.

Nasution, Harun. Filsafat dan Mistisisme dalam Islam. Jakarta: Bulan Bintang, 1990.

-----. Teologi Islam: Aliran-aliran Sejarah Analisa Perbandingan. Jakarta: UI Press, 1986.

Purwadi, Agus. Teologi Filsafat dan Sains. Malang: UMM-Press, 2002.

Putro, Suadi. Mobammed Arkoun Tentang Islam dan Modernitas. Jakarta: Paramadina, 1995.

Qamaly, Sayid al-Asghar al-Nazim al-. Al-Fushul al-Mi'ab fi Hayati Amir al-Mu'minin Ali bin Abi Thalib. Muhr Qum: tp., 1992.

Rachman, Budhy Munawwar. "Tradisi dan Masa Depan Filsafat Islam”, dalam Ulumul Qur'an, No. 3 Vol. I, 1989, 102.

Rahman, Fazlur (terj.). Metode dan Alternatif Neomodernisme Islam. Bandung: Mizan, 1994.

Rahnema, Ali. Pioneers of Islamic Revival. Terjemah Ilyas Hasan, Para Printis Zaman Baru Islam. Bandung: Mizan, 1995.

Sho'ub, Hasan. Islam dan Revolusi Pemikiran: Dialog Kreatif Ketubanan dan Kemanusiaan. Surabaya: Risalah Gusti, 1997.

Stanton, Charles Michael (terjemah). Pendidikan Tinggi dalam Islam. Jakarta: Logos Publishing House, 1994.

Syahrastani, Muhammad bin Abdul Karim al-. al-Mihal wa al-Nihal. Beirut: Dar al-Fikr, tt.

TAJDID vol. 17, No. 2, Juli - Desember 2018 | 201 
Abd. Latif

Watt, W. Montgomery. Islamic Philosophy and Theology. Edinburgh: Edinburgh University Press, 1985.

-----. The Formative Period of Islamic Thought. Edinbergh: The University Press, 1973.

Yatim, Badri. Sejarah Peradaban Islam. Jakarta: RajaGrafindo Persada, 1997.

Yusuf, M. Yunan. Alam Pikiran Islam: Pemikiran Kalam. Jakarta: Perkasa, 1990.

202 | TAJDID vol. 17, No. 2, Juli - Desember 2018 